\title{
АЕРЖАВНЕ УПРАВ $\Lambda$ ІНЯ
}

DOI: https://doi.org/10.32839/2304-5809/2020-1-77-41

УДК 342.571

Фоміна О.О., Голуб П.А.
ДВНЗ «Донецький національний технічний університет»

\section{ПІДВИЩЕННЯ ДОВІРИ ДО СУДОВОЇ ВЛАДИ ЯК ПОКАЗНИК РОЗВИТКУ УКРАЇНСЬКОГО СОЦІУМУ}

Анотація. Необхідною умовою панування принципу верховенства права в державі є довіра населення до судових інстанщій та системи здійснення правосуддя загалом. Стаття присвячена постановці проблеми розвитку судової влади в Україні та довіри до неї з боку соціуму, їх підтримка органами державної влади, що генерують та виконують «правила гри» суспільної взаємодії, забезпечують функціональність «інструментів демократії». Визначається поняття «довіри» та здійснюеться ï аналіз як соціальної інституції. У даній статті формулюються головні засади національного моніторингу рівня довіри до суду та судової системи на основі аналізу особливостей сучасної української ситуащії в цій серері. Вказуються основні фрактори, які впливають на рівень довіри населення до судових інстанщій та системи здійснення правосуддя. Автором робиться висновок про необхідність подальшого удосконалення та реформування судової влади в Україні 3 метою виправлення існуючих недоліків та підвищення довіри суспільства до суду та судової системи.

Ключові слова: довіра, судова влада, легітимність, державне управління, український соціум.

Fomina Olena, Holub Pavlo Donetsk National Technical University

\section{INCREASING OF TRUST TO THE JUDICIARY AS AN INDICATOR OF THE DEVELOPMENT OF THE UKRAINIAN SOCIETY}

Summary. A necessary condition for the rule of law in the state is the public's trust in the courts and the system of justice in general. The main purpose of the court is to resolve conflicts and disputes that arise in society. The Court's activities are intended to reconcile, relieving tension and confrontation, as justice has the function of stabilizing and reconciling. The article is devoted to the statement of the problem of the development of the judiciary in Ukraine and trust in it by the society, their support by the state authorities, which generate and implement the "rules of the game" of social interaction, ensure the functionality of the "instruments of democracy". The concept of "trust" is defined and analyzed as a social institution. Trust is an informal social institution that provides certain decisions, actions, behaviors from the parties involved, influencing the decisions that are guided by the subjects of social relations. A high level of trust in government institutions makes them legitimate, able to work and, conversely, a low level of trust in government institutions diminishes their social significance. At the same time, a positive history of the work of a governmental institution arouses and supports the trust of social interaction entities. The lack of confidence in the judiciary is a major problem for the Ukrainian society, the entire socio-economic system, law and justice. The main principles of national monitoring of the level of trust in the court and the judicial system are formulated in this article based on the analysis of the peculiarities of the current Ukrainian situation in this area. The main factors that influence the level of public confidence in the courts and the justice system are outlined. The author concludes that there is a need for further improvement and reform of the judiciary in Ukraine in order to correct existing shortcomings and increase public confidence in the court and the judicial system. Increasing of confidence in the judiciary in Ukraine will help to improve relations between the state and the society, reduce corruption in the material and intangible spheres, increase financial and economic activities, as a consequence of increased budgetary revenues, which are the prospects for further research.

Keywords: trust, judiciary, legitimacy, public administration, Ukrainian society.

$\Pi$ остановка проблеми. Сучасна судова влада - це незалежна і самостійна гілка державної влади, яка здійснюеться судами. За допомогою судів виконується внутрішньоорганізаційне державне управління, а органи судової влади відповідають за відповідність законів Конституції i підзаконних нормативних актів законам. У свою чергу, активна позиція громадян у позиціюванні своїх прав і врегулюванні наявних конфліктів через суди підштовхнула до усвідомлення державою важливості якісного виконання належних фрункцій відповідно до принципів демократії. Сучасна судова влада є гілкою державної влади, яка забезпечуе панування права в суспільних відносинах, в тому числі і щодо держави. Опосередковані правом суспільні відносини схематично можна записати наступним чином: «суспільство» $\leftrightarrow$ «право» $\leftrightarrow$ «суспільство» та «суспільство» $\leftrightarrow$ «право» $\leftrightarrow$ «держава». Судова влада тут 3 одного боку виступає функцією держави щодо підтримання правопорядку і вирішення конфрліктів в суспільних відносинах, а 3 іншого - контролюеться громадянським суспільством, оскільки формалізоване право створюється для встановлення оптимальних правил взаємодії між людьми. Такий обмін правами між державою і соціумом дозволив владі отримати легітимність і можливість здійснювати державне управління шляхом суспільного визнання i поєднання інтересів людей 3 їх внутрішніми 
оцінками, що дає можливість будувати сильну незалежну демократичну державу. Водночас, це надає особливого статусу питанню довіри соціуму до судової влади, що обумовлюе актуальність нашого дослідження.

Аналіз останніх досліджень та публікацій. Довіра представляе собою нефрормальний соціальний інститут, що передбачає очікування певних рішень, вчинків, поведінки від сторін взаємодії, що впливають на рішення, якими керуються суб'єкти сощіальних відносин. Високий рівень довіри до владних інституцій робить їх легітимними, працездатними i, навпаки, низький рівень довіри до владних інституцій знижуе їх соціальну значимість. Одночасно позитивна історія роботи владної інституції викликає і підтримуе до неї довіру з боку суб'єктів соціальної взаємодії [3, с. 216]. Недовіра до судової влади є великою проблемою українського соціуму, всіеї соціальноекономічної системи, права і судочинства. Розвиток судочинства і проблеми довіри до судової влади є предметом дослідження іноземних та вітчизняних науковців $[1 ; 2 ; 8 ; 11 ; 13]$. Суттевий внесок в підтримку законності в межах контролю і нагляду за судовою владою зробили такі автори, як Г. Бребан [1] та Б. Гурне [2]. Свого часу, Ш. Монтеск'є [8], а згодом, і М. Суховій [11] внесли пропозищії щодо фрункцій судової влади. Особливу увагу слід звернути на монографрію за редакцією І. Б. Усенко [13], в якій було зроблено огляд історії держави та права України та розкрито певні питання довіри до судової влади протягом часу, перетворення судової влади на соціальний інститут. Щодо дослідження довіри, то тут слід виділити роботи Жуковської О. [3], Зеленько Г. [5], які безпосередньо стосуються формування інституту довіри, довіри до суспільно-політичних інститутів та її ролі для українського суспільства. Зважаючи на чисельність досліджень, які були проведені в напрямку розвитку судової влади та формування інституту довіри в українському сощіумі, їх не можна вважати завершеними, оскільки недостатньо опрацьовані підходи до визначення ролі довіри в розвитку інститутів влади, зокрема судової влади, їі значення в аспекті державного управління, що і зумовило вибір теми і постановки мети даної статті.

Мета статті полягае у висвітленні проблеми довіри до судової влади як показника розвитку українського соціуму та виявленні наслідків низького рівня довіри та перспектив підвищення.

Виклад основного матеріалу дослідження. Інститут довіри є дуже важливим ресурсом формування громадянського суспільства, дефіцит якого може бути невидимим гальмом розвитку, показником неедективності проваджуваних редрорм. Суспільна довіра є умовою інтеграції сощіуму навколо тих чи інших суспільно значущих проблем, успішного реформування соціальноекономічної системи держави [5, с. 108]. Однією 3 таких проблем є розвиток судової влади в Україні та довіри до неї з боку соціуму, їх підтримка органами державної влади, що генерують та виконують «правила гри» суспільної взаємодії, забезпечують фрункціональність «інструментів демократії» (виборів, різноманітних дрорм політичної та громадської участі тощо). Така довіра є інституціоналізованою, вона залучає уряд, бізнес, 3МІ, профрспілки та ін. до фрормування та розвитку громадянського суспільства. Чим вища інституціоналізована довіра, тим стійкіша суспільна система, довіра виступає своєрідним «термометром» здоров'я суспільства [7, с. 151].

Відповідно до [13, с. 32] судова влада $є$ функціонально та інституційно відособленою сфрерою публічної влади, сукупністю владних повноважень судів та інших уповноважених суб'єктів, легітимізованих волею народу або іншого конкретноісторичного суб'єкта легітимації, що здійснюють свою діяльність для підтримання правопорядку, забезпечення соціальної злагоди, реалізації інтересів громадянського суспільства в спеціальних процесуальних формах правосуддя, а також тлумачення норм права та контроль за державними органами та посадовими особами. 3 визначення випливає, що довіра до судової влади залежить від політики проваджуваної державою, оскільки саме держава формує правила взаємодії суб'єктів господарювання 3 урахуванням інтересів громадянського суспільства. При цьому слід зазначити, що ідеальний суб'єкт соціальної взаємодії є цілераціональним, утилітарним, емпатичним, 3 очікуваною поведінкою в умовах, що склалися, тобто володіє ресурсом суспільної довіри [9, с. 22-23]. Проблема довіри до судової влади полягає у тому, що в політичному середовищі завжди існуе можливість рентоорієнтованої поведінки прагнення суб'єктів господарювання поставити сили і можливості держави на службу конкретним приватним інтересам: по-перше, урядовці прагнуть отримати вигоди за рахунок суспільства в цілому, так і за рахунок груп спеціальних інтересів; по-друге, політики, зацікавлені у прийнятті рішень, які забезпечать їм негайні вигоди і зростання популярності; по-трете, існуе група спеціальних інтересів, у разі прийняття вигідного їй рішення буде отримувати додаткові вигоди за рахунок суспільства (монопольний статус, ліцензію на унікальну діяльність, субсидії, пільги по кредитах) [12, с. 55]. Таким чином, виникає гонитва за рентою, пов'язана 3 використанням владних повноважень держави, відбувається зниження ресурсу суспільної довіри, що вимагає спеціальних заходів з боку держави.

3 метою «ідеалізації» суспільних відносин, підвищення авторитету судової влади України та довіри громадян до судової гілки влади у 2014 рощі Верховною Радою України було прийнято чинний i на сьогодні Закон України «Про відновлення довіри до судової влади в Україні» від 08.04.2014 № 1188-VII [4], яким визначено правові та організаційні засади проведення спеціальної перевірки суддів судів загальної юрисдикції, притягнення суддів судів загальної юрисдикції до дисциплінарної відповідальності та звільнення 3 посади у зв'язку з порушенням присяги. Фактором зростання довіри до судової влади виступає рівень прозорості й відкритості цих органів, дотримання ними «правил гри», законності і елементарної соціальної справедливості [5, с. 113].

Розуміючи проблему з практичного боку, держава здійснюе ії моніторинг в межах Програми «USAID» «Нове правосуддя» [10] для виявлення динаміки думок респондентів, їх відношення до органів державної влади, та паралельно проводить редрорми, які націлені на якісні зміни 


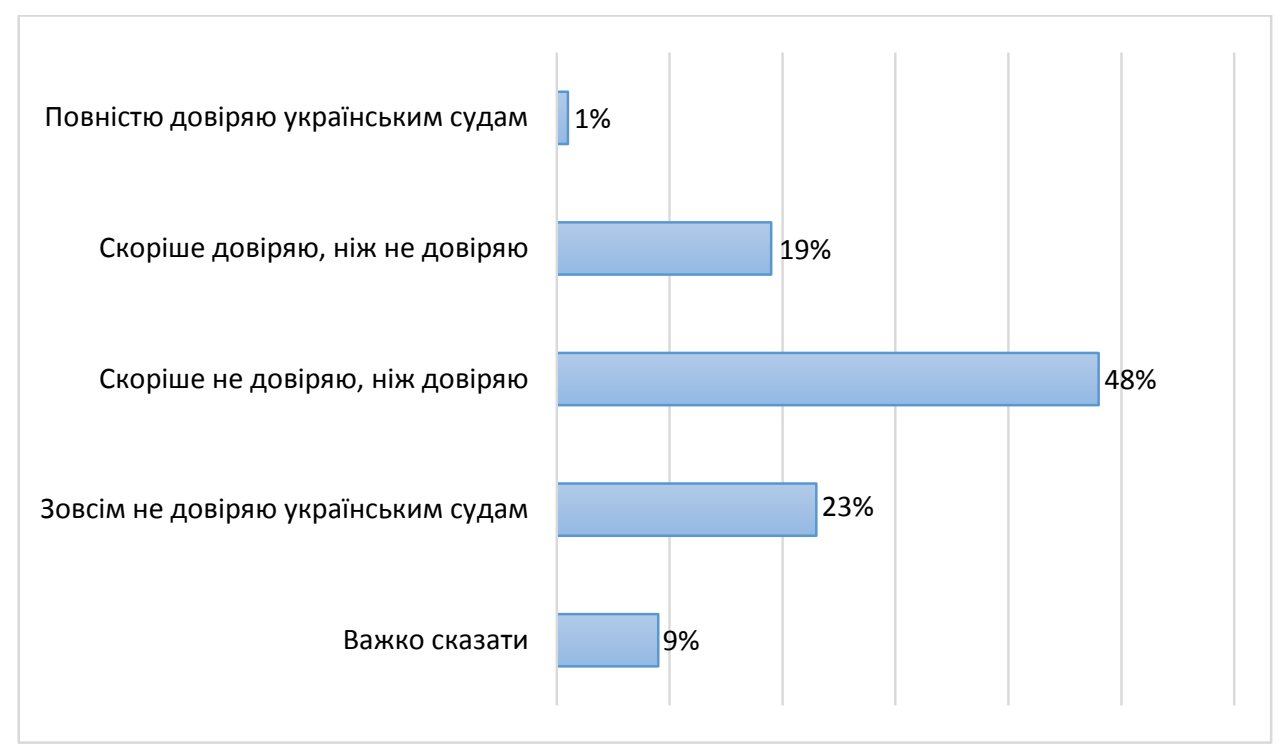

Рис. 1. Довіра до судової влади в Україні у 2018 р. за шкалою системи «Свробарометр» Джерело: [10]

у всіх сdрерах життедіяльності українського соціуму, зокрема, через впровадження системи електронного урядування, електронного судочинства тощо, що забезпечують певний рівень прозорості і відкритості, контроль за якими покладено на суспільство через зворотній зв'язок 3 органами влади та спеціальний механізм. Результати реалізації Програми «USAID» «Нове правосуддя» зводяться до наступного.

По-перше, судова редорма в Україні сприяє підвищенню суспільної довіри до судової та інших гілок влади; по-друге, антикорупційні заходи української влади зменшують толерантність суспільства корупції та посилюють участь громадськості в боротьбі з корупцією; по-трете, населення та пращівники сектору юстищії володіють індрормацією про судову рефрорму та сприймають ïi позитивно; по-четверте, думка профресійних юристів щодо незалежності та підзвітності судової влади, її безсторонності та едеккивності 30бражує об'єктивно поточний стан судової системи, таким чином їхне сприйняття судової влади $є$ показником успіху судової редрорми [10].

В рамках програми «USAID» «Нове правосуддя» було проведено опитування, відповідно до якого 2478 респондентів (з яких, жінки - 55\%, чоловіки - 45\%) висловили своє ставлення до судової влади в Україні. Так у 2018 р. за шкалою системи «Свробарометр» виявили схильність довіряти судовій владі $20 \%$ респондентів (1\%, які повністю довіряють, та 19\%, які скоріше довіряють), схильність недовіряти - 71\% (48\%, які скоріше недовіряють, та $23 \%$, які зовсім не довіряють), не змогли визначитися - 9\%, що представлено на рисунку 1.

3 метою виявлення рівня довіри до судової влади за регіональною ознакою, респондентів було поділено за макрорегіонами: захід (Волинська, Закарпатська, Івано-Франківська, Львівська, Рівненська, Тернопільська, Чернівецька); північ (Житомирська, Київська, Сумська, Чернігівська); центр (Вінницька, Дніпропетровська, Кіровоградська, Полтавська, Хмельницька, Черкаська); південь (Запорізька, Миколаївська, Одеська, Херсонська); схід (Харківська, Донецька та Луганська (території підконтрольні Україні), м. Київ, результати представлено у таблищі 1.

Максимальний рівень недовіри до судової влади виказав «Східний» регіон, однак порівнюючи показники довіри 3 показниками недовіри маємо досить велике значення їх співвідношення за всіма регіонам України, внаслідок чого це проблема загальнодержавного значення.

Таблиця 1

Рівень довіри до судової влади України за регіональним розподілом у 2018 р., \%

\begin{tabular}{|l|c|c|c|c|c|c|c|}
\hline $\begin{array}{c}\text { Рівень довіри (відповіді } \\
\text { респондентів) }\end{array}$ & Захід & Центр & Південь & Схід & Північ & м. Київ & Всього \\
\hline Зовсім не довіряю & 31 & 28 & 29 & 27 & 31 & 27 & 29 \\
\hline Скоріше не довіряю & 27 & 26 & 32 & 42 & 26 & 34 & 30 \\
\hline Нейтрально (і довіряю, і не довіряю) & 16 & 26 & 21 & 20 & 19 & 23 & 21 \\
\hline Скоріше довіряю & 18 & 12 & 12 & 7 & 14 & 10 & 13 \\
\hline Повністю довіряю & 6 & 3 & 2 & 0 & 4 & 3 & 3 \\
\hline Важко відповісти & 2 & 4 & 4 & 3 & 6 & 3 & 3 \\
\hline Відмова від відповіді & 0 & 0 & 0 & 0 & 0 & 0 & 0 \\
\hline ТОТАL & 100 & 100 & 100 & 100 & 100 & 100 & 100 \\
\hline
\end{tabular}

Джерело: [10] 
Таблиця 2

Динаміка показників довіри до судової влади за 2015-2018 рр., \%

\begin{tabular}{|c|c|c|c|c|c|c|c|c|}
\hline \multirow[b]{2}{*}{ Групи респондентів } & \multicolumn{2}{|c|}{2015 p. } & \multicolumn{2}{|c|}{2016 p. } & \multicolumn{2}{|c|}{2017 p. } & \multicolumn{2}{|c|}{2018 p. } \\
\hline & 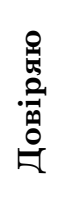 & 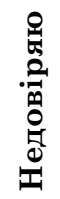 & 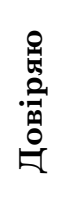 & 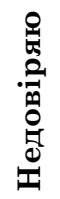 & 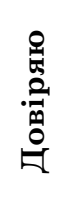 & 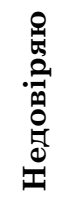 & 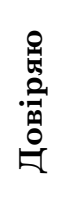 & 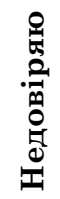 \\
\hline Населення в цілому & 5 & 79 & 10 & 69 & 12 & 65 & 16 & 59 \\
\hline Учасники судових проваджень & 16 & 66 & 13 & 67 & 28 & 50 & 34 & 39 \\
\hline Професійні правники & - & - & - & - & 38 & 18 & 41 & 16 \\
\hline
\end{tabular}

Джерело: [10]

Наслідки низького рівня довіри проявляються у гальмуванні процесів суспільного розвитку. Разом 3 тим, динаміка показників оцінки довіри до судової влади протягом 2015-2018 рр., що представлена у таблиці 2, свідчить, що довіра населення поступово підвищується: у 2015 р. вона склала 5\%, у 2016 р. - 10\%, у 2017 р. - 12\%, а у 2018 р. було досягнуто максимальне значення $-16 \%$. Водночас, показник довіри до судової влади учасників судових проваджень досяг мінімального значення у 2016 р. $-13 \%$, а починаючи 32017 р. спостерігається зростання показника, значення якого досягло максимального значення у 2018 р. - 34\%. Переломним виступає 2016 рік, коли довіра починає зростати. Рівень довіри до професійних правників зростає: $38 \%$ у 2017 р. та $41 \%$ у 2018 р.

Незважаючи на те, що для громадян України зазвичай найважливішою проблемою є власний соціально-економічний добробут, від державних інституцій вони насамперед очікують забезпечення соціальної справедливості і законності. Проведений аналіз показників довіри вказує на поступове, хоча і не дуже значне, вирішення проблеми довіри до судової влади в Україні. Позитивна динаміка може бути пояснена 3 позищій Ф. Фукуями [14]: коли члени групи очікують, що інші будуть поводитися чесно, і на них можна покластися, вони починають довіряти один одному, довіряти суб'єктам соціальної взаємодії. "Довіра діє як мастило для двигуна, що дає змогу будьякій групі чи організації працювати більш ефрективно» [5, с. 115]. Таким чином, довіра виступає джерелом суспільного розвитку.

Висновки та перспективи подальших досліджень. Узагальнення результатів до- слідження довіри до судової влади дає можливість визнати: проблема довіри до судової влади не $е$ новою для України, водночас вона набула особливих сучасних ознак, які пов'язані 3 необхідністю проведення реформ більш швидкими темпами, що позитивно відбиваеться на якісних та кількісних показниках розвитку державного управління; відбуваються поступові зміни негативного на більш позитивне ставлення українського соціуму до судової влади. Однак, для формування всезагального позитивного ставлення до державних інститутів, діяльність яких спрямована на забезпечення "правил гри», законності і елементарної соціальної справедливості потрібен більш тривалий проміжок часу і відповідне ставлення та підтримка органів державної влади, зокрема, державного управління. Серед ключових передумов творення простору суспільної довіри в Україні велике зазначення має необхідність врахування особливостей українського соціуму, переважних ціннісних орієнтацій господарюючих суб'єктів та їх інтересів, специфічних умов та можливостей їх трансформації на шляху розвитку демократичної держави. Саме довіра виступає як норма, що регулює взаємовідносини суб'єктів господарювання. Довіра сприяе передбачуваності поведінки суб'єктів взаємодії та формуванню чітких очікувань результатів соціальної взаємодії. Підвищення довіри до судової влади в Україні сприяє покращенню відносин між державою і суспільством, зменшенню корупції у матеріальній і нематеріальній сфрерах, підвищенню активності у фрінансово-господарської діяльності, як наслідок збільшенню надходжень до державного бюджету, що є перспективами подальших досліджень.

\section{Список літератури:}

1. Брэбан Г. Французское административное право. Пер. с фрр. / Под ред. и со вступ. ст. С.В. Боботова. Москва : Прогресс, 1988. 488 с.

2. Гурне Б. Державне управління; пер. з фрр. пер. Віктор Шовкун. Київ : Основи : Ін-т держ. упр. та самоврядування при Кабінеті Міністрів України : Преса України, 1993. 165 с.

3. Жуковская Е.В. Доверие как норма и процесс ее институционализации. Бізнес Інборл. 2011. № 8. С. $214-216$.

4. Про відновлення довіри до судової влади в Україні : Закон України від 08 квітня 2014 р. № 1188-VII / Верховна Рада України. URL: https://zakon.rada.gov.ua/laws/main/1188-18 (дата звернення: 13.12.2019).

5. Зеленько Г.І. Довіра до суспільно-політичних інститутів в Україні і наслідки ії дефіциту для країни. Studia Politologica Ucraino-Polona. 2018. Вип. 8. С. 108-118.

6. Конституція України: Закон від 28 червня 1996 р. № 254к/96-ВР / Верховна Рада України. URL: https://zakon.rada.gov.ua/laws/show/254к/96-вр (дата звернення: 13.12.2019).

7. Мартинюк I., Соболева Н. Формування довіри як передумова інтеграції суспільства: довірчі відносини в сучасному українському соціумі. Українське суспільство: моніторинг соціальних змін. 2016. Вип. 3(17). С. $150-166$.

8. Монтескье Ш.Л. О духе законов и об отношениях, в которых законы должны находиться к устройству каждого правления, к нравам, климату, религии, торговле и т.д.; под ред. А.Г. Горнфельд; вступ. ст. М.М. Ковалевского; пер. с фр. Санкт-Петербург : Изд. Л.Ф. Пантелеев, 1900. 394 с. 
9. Олейник А.Н. Институциональная экономика : учебное пособие. Москва : ИНФРА-М, 2002. 416 с.

10. Результати другого всеукраїнського опитування населення України щодо довіри судової влади, судової реформи, сприйняття корупщії, проведеного програмою USAID «Нове правосуддя» у жовтні 2018 року. URL: https://newjustice.org.ua/wp-content/uploads/2018/11/1_NJ_October_2018_SurveyPublic_Result_UKR.pdf (дата звернення: 13.12.2019).

11. Суховій М.М. Правовий статус інституту судової влади у контексті судово-правової реформи в Україні : дис. ... канд. юрид. наук. Львів, 2012. 240 с.

12. Турлакова А.С. Природа сучасної інституційної корупції. Соціальна еконоліка. 2016. № 2. С. 54-60.

13. Усенко І.Б. Судова влада в Україні: історичні витоки, закономірності, особливості розвитку: монографрія; за ред. І.Б. Усенко. Київ : НВП Видавництво «Наукова думка» НАН України, 2014. 501 с.

14. Фукуяма Френсіс. Соціальний капітал. Переклад: Лілія Шевчук. Незалежний культурологічний часопис «ї». Культура має значення. 2008. № 53. URL: http://www.ji.lviv.ua/n53texts/fukuyama.htm

\section{References:}

1. Breban, G. (1988) Frantsuzskoye administrativnoye pravo [French administrative law]. Moscow: Progress, 488 p. (in Russian)

2. Hurne, B. (1993) Derzhavne upravlinnia [Public administration]. Kyiv: Osnovy, 165 p. (in Ukrainian)

3. Zhukovskaia, E.V. (2011). Doveriye kak norma i protsess eye institutsionalizatsii [Trust as a norm and the process of its institutionalization]. Business Inform, no. 8, pp. 214-216. (in Russian)

4. Pro vidnovlennia doviry do sudovoi vlady v Ukraini [On restoring confidence in the judiciary in Ukraine] : Zakon Ukrainy vid 08 kvitnia 2014 r. no. 1188-VII / Verkhovna Rada Ukrainy. Available at: https://zakon.rada.gov.ua/ laws/main/1188-18 (accessed 13 December 2019).

5. Zelenko, H.I. (2018). Dovira do suspilno-politychnykh instytutiv v Ukraini i naslidky yii defitsytu dlia krainy [Trust to social and political institutes: and the effects of its deficiency in Ukraine]. Studia Politologica UcrainoPolona, vol. 8, pp. 108-118. (in Ukrainian)

6. Konstytutsiia Ukrainy [Constitution of Ukraine] : Zakon vid 28 chervnia 1996 r. no. 254к/96-BP / Verkhovna Rada Ukrainy. Available at: https://zakon.rada.gov.ua/laws/show/254к/96-вр (accessed 13 December 2019).

7. Martyniuk, I., \& Sobolieva, N. (2016). Formuvannia doviry yak peredumova intehratsii suspilstva: dovirchi vidnosyny $\mathrm{v}$ suchasnomu ukrainskomu sotsiumi [Building trust as a prerequisite for social integration: trust in today's Ukrainian society]. Ukrainske suspilstvo: monitorynh sotsialnykh zmin, vol. 3(17), pp. 150-166. (in Ukrainian)

8. Montesk'ye, Sh.L. (1900). O dukhe zakonov i ob otnosheniyakh, v kotorykh zakony dolzhny nakhodit'sya $k$ ustroystvu kazhdogo pravleniya, $k$ nravam, klimatu, religii, torgovle $i$ t.d. [The spirit of the laws and the relationships in which the laws must reside in the structure of each government, the mores, the climate, religion, commerce, etc.]. Saint Petersburg: L.F. Panteleyev, 394 p. (in Russian)

9. Oleynik, A.N. (2002). Institutsional'naya ekonomika: Uchebnoye posobiye [Institutional Economics: A Textbook]. Moscow: INFRA-M, 416 p. (in Russian)

10. U.S. Agency for International Development (USAID) (2018). Rezultaty druhoho vseukrainskoho opytuvannia naselennia Ukrainy shchodo doviry sudovoi vlady, sudovoi reformy, spryiniattia koruptsii, provedenoho prohramoiu USAID "Nove pravosuddia" u zhovtni 2018 roku [Results of the Second All-Ukrainian Population Survey of Ukraine on Judicial Trust, Judicial Reform, Perception of Corruption by USAID New Justice in October 2018]. Available at: https://newjustice.org.ua/wp-content/uploads/2018/11/1_NJ_October_2018_SurveyPublic_ Result_UKR.pdf (accessed 13 December 2019).

11. Sukhovii, M.M. (2012). Pravovyi status instytutu sudovoi vlady u konteksti sudovo-pravovoi reformy $v$ Ukraini [Legal status of the Judiciary in the context of judicial reform in Ukraine] (PhD Thesis). Lviv: Lviv University of Business and Law, 240 p. (in Ukrainian)

12. Turlakova, A.S. (2016). Pryroda suchasnoi instytutsiinoi koruptsii [The nature of modern institutional corruption]. Sotsialna ekonomika, no. 2, pp. 54-60. (in Ukrainian)

13. Usenko, I.B. (2014). Sudova vlada v Ukraini: istorychni vytoky, zakonomirnosti, osoblyvosti rozvytku [Judiciary in Ukraine: Historical Origins, Patterns, Features of Development: Monograph]. Kyiv: Naukova dumka, 501 p. (in Ukrainian)

14. Fukuiama Frensis (2008). Sotsialnyi kapital [Social capital]. Nezalezhnyi kulturolohichnyi chasopys "Yi». Kultura maie znachennia, no. 53. Available at: http://www.ji.lviv.ua/n53texts/fukuyama.htm (accessed 13 December 2019). 